\title{
TRANSLATION OF NONVERBAL COMMUNICATION IN THE AFRIKAANS BIBLE VERSION FOR THE DEAF: A SHORT NOTE
}

\author{
Francois T de Villiers \\ Department of Old and New Testament \\ University of Stellenbosch
}

\begin{abstract}
The new Afrikaans Bible translation for the Deaf is currently under way. This translation attempts to translate the meaning of the source texts into the linguistic constraints of the Afrikaans Deaf, broadly following the translation theory of Eugene Nida. This article attempts to be part of a debate concerning the translation of non-verbal communication in the Bible. I point out that non-verbal communication is a meaningful element of communication in the text and that it must be translated accordingly if the Afrikaans translation for the Deaf, and any other translation following the same theoretical framework, wants to be consistent with its own presuppositions. I illustrate my point by referring to Job 30:28.
\end{abstract}

\section{Nonverbal communication in the Bible: The problem of definition}

In his study on nonverbal communication in the Ancient Near East, Gruber (1980:22) refers to a statement by the anthropologist, Ray L Birdwhishtell, that "...each verbal language tends to be accompanied by a well-developed language of postures, gestures, and facial expressions operating in consonance with verbal language to effect communication."

Gruber (1980:17) argues convincingly that these references to nonverbal information in the text, sometimes function as morphemes in language. This means that these nonverbal references communicate meaning, i.e. they are part of the message of the Bible; just like the words/sentences that are translated, nonverbal communication must also be translated. Malul (1988:17) tries to take seriously that our source for studying nonverbal communication in the ancient world, is a text. This means that our point of departure is a text containing "remarks alluding to [nonverbal] symbolic acts" (Malul 1988:17 and cf. Viberg 1992:9).

Kruger (1998:144) indicates that definition of "nonverbal communication" is a major problem. The problem of terminology has caused that every study of "non-speech" calls for a redefining of the subject matter. Another problem is that various studies have indicated that nonverbal information can occur in so many categories, that each new definition requires a careful positioning and justification in terms of the various categories which are available (Ekman \& Friesen 1969:49). Thus far there exists no single or clear cut conceptual model with which to analyse and interpret this nonverbal aspect of language (Botha 1996:15).

Nonverbal information is to be found in the Bible in various contexts in both the New Testament (Botha 1996:11) ${ }^{1}$ and the Old Testament (Kruger 1998:147). ${ }^{2}$ In my recent study

1. Two examples might be references to Paul making a gesture before beginning a speech in Acts 21:40 and reference to a "handshake" in Galatians 2:9.

2. Kruger (1998:147) uses the terms "legal symbolic acts," "emotional displays" and "religious symbolism." 
I opted for a definition which comes down to the nonverbal expression of a certain emotion (De Villiers 2002:42) and many more are possible.

Despite the use of the term "nonverbal communication" in various contexts, what makes the study of nonverbal information significant for Bible translation, is the fact that Gruber (1980) has indicated convincingly that such nonverbal references in a text contain meaning. This is a very important point to consider, especially if a specific Bible translation states explicitly that its theoretical point of departure is the conveyance of meaning.

\section{The Afrikaans Bible translation for the deaf}

Combrink (2002:298) states that the translation project of the Afrikaans Bible for the Deaf (ABD) will be based broadly on the functional equivalent approach. Combrink refers to the well known work by De Waard and $\mathrm{Nida}^{3}$ in this regard. Combrink (2002:298) states: "What the original text communicated has to be conveyed as accurately as possible in the ABD within the linguistic constraints of the language used by the Afrikaans deaf."

In terms of its own presuppositions (Naudé 2000:15) a critical question to pose to a translation such as the ABD would be whether and in what way it adheres to its own point of departure. This means that if the ABD intends to convey meaning from a text to a translation, it must make sure that a meaningful/meaning-containing element in the source text is translated as such. This means that also nonverbal information in the text which contains meaning, must be translated in such a way that the reader will grasp its meaning. The manner in which it must be conveyed is surely a debate on its own. The linguistic constraints of the Deaf are broadly based on the fact that Deaf ${ }^{4}$ people learn words and language differently that hearing people do. ${ }^{5}$ Therefore a translation that has the specific needs of the Afrikaans Deaf in mind whilst approaching both the audience and source text from the theoretical framework of functional equivalence, must keep the following in mind: Apart from the fact that the final translation should try to avoid the use of passives, some idioms that the Deaf can not understand, unique syntax and difficult words in order to take into account the linguistic constraints of the Deaf, meaningful elements in the souce text must be translated as such, i.e. if something has meaning in the source text, this meaning must be conveyed in translation in a language that the receptor audience can understand. In this regard, translators of the Afrikaans Bible for the Deaf should be aware of the presence of nonverbal information in the source text, by certain criteria decide whether it has meaning or not, and translate it in such a way that the audience will understand it as meaningful.

There are nonverbal references in the source text. It has been indicated convincingly many times in the past that such references to nonverbal information in the text often convey meaning. Meaningful nonverbal communication in the source text is often missed by translators (Barré 2001:187). If the ABD wishes to be faithful in terms of its own presuppositions, it must seriously consider what it intends to do with instances of nonverbal communication in the text, so that its meaning is clear in translation.

3. De Waard, J \& Nida, EA 1987. From one language to another: Functional equivalence in Bible translating. Nashville: Thomas Nelson.

4. Deaf with a capital letter is to be distinguished from deaf with a small letter. "Deaf" refers mostly to a group of people who use sign language to communicate, i.e. it is a cultural term, whilst "deaf" refers to the state, from a medical point of view, where a person is unable to hear sound.

5. It is interesting that in South African Sign Language the symbol for a "hearing person" has to do with the ability to talk verbally with the mouth/ lips. 


\section{An example: Job 30:28}

The text of Job 30:28 is problematic for several reasons (Reyburn 1992:556). A meaningorientated translation such as the ABD would experience great trouble at this verse, especially since no satisfactory explination has thus far been given for the problematic combination of "going about/walking around whilst becoming dark" on philological grounds and that the rest of the verse is equally obscure due to the uncertain words in the second half of the verse.

Many translations seem to follow Delekat (1964:55) that the meaning of the root "to be dark" refers to emotion. De Waard (1972:20) even considers whether the combination "going about/walking around whilst becoming dark" might not be the remnant of a funeral dance in Ancient Israel.

However, if we are sensitive to the possibilities of nonverbal information in the text, the focus would fall on the verb "to go/walk about," i.e. Job is doing (vs. saying) something in order to communicate. Barré (2001:181) argues convincingly that the combination "going about/walking around whilst becoming dark" refers to the nonverbal expression of depressive emotion.

Job 30:28 is an example of nonverbal communication; it has meaning. The ABD would have to convey the meaning of this nonverbal communication in translation. One can argue whether or not the English Version for the Deaf (EVD) is sensitive to the meaning of nonverbal communication in the text. The EVD reads Job 30:28 as follows:

\section{I am always sad and depressed, without relief.}

It is interesting that the EVD, which also intends to convey the meaning of the text to an audience within certain linguistic constraints, interprets the expression "going about/walking around whilst becoming dark" as emotion and conveys the meaning as such. It strikes me that the EVD does not provide this verse with a footnote to explain some of the difficult words. The Afrikaans Deaf have sign language symbols referring to the "long face" - perhaps this or even an explanitory drawing could help convey the meaning, because Job was not only sad and depressed - he was also showing that he was sad and depressed.

An interesting point of discussion for further study, is in what way could nonverbal communication be translated for an audience which is more nonverbally inclined. Should only the meaning of nonverbal communication be conveyed, providing a footnote if the words are difficult to understand or abstract? Should a recognised sign in South African Sign Language be attatched to this expression (Nieder-Heitmann 1980:85)? Would a person signing the text in a church lection be able to use the translation of the ABD or later the Afrikaans Bible for the Deaf in order to use the correct sign language symbol? Would Deaf people be able to understand this emotion better if an abstract noun is used or if the nonverbal communication in the source text is translated as such? 


\section{BIBLIOGRAPHY}

Barré, ML 2001. "Wandering about" as a topos of depression in Ancient Near Eastern literature and in the Bible. Journal of Near Eastern Studies 60(3):177-187.

Botha, JE 1996. Exploring gesture and nonverbal communication in the Bible and the ancient world: some initial observations. Neotestamentica 30(1):1-19.

Combrink, C 2002. The Afrikaans Translation of the Bible for the Deaf. Scriptura 77:297302.

De Waard, EF 1972. Mourning Customs in 1, 2 Samuel. Journal of Jewish Studies 23(1):127.

De Villiers, FT 2002. Woordlose taal: oor die belang van nie-verbale kommunikasie vir die vertaling van die boek Job. Ongepubliseerde MDiv-skripsie: Universiteit van Stellenbosch.

Ekman P \& Friesen, WV 1969. The repertoire of nonverbal behavior: categories, origins, usage and coding. Semiotica 1:49-98.

Gruber, MI 1980. Aspects of Non-Verbal Communication in the Ancient Near East. Rome: Biblical Institute Press.

Kruger, PA 1998. "Nonverbal Communication" in the Hebrew Bible: a few comments. Journal of Northwest Semitic Languages 24(1):141-164.

Naudé, JA 2000. Translation Studies and Bible Translation. Acta Theologica 2000(1): $1-27$.

Nieder-Heitmann, N 1980. Talking to the Deaf. Pretoria: Department of Education and Training and S.A. National Council for the Deaf.

Reyburn, WD 1992. A Handbook on the Book of Job. New York: United Bible Societies.

Viberg, Å 1992. Symbols of Law: A Contextual Analysis of Legal Symbolic Acts in the Old Testament. Stockholm: Almqvist \& Wiksell International.

World Bible Translation Center. 1992. Holy Bible: English Version for the Deaf. Translated from the original languages. Grand Rapids: Baker Book House. 